\title{
Dietary changes and colorectal cancer trends in Spain during 1951-2007
}

\author{
L. Béjar ${ }^{1}$, M. Gili1 ${ }^{1,2}$, G. Ramírez², J. López ${ }^{1,2}$ and J. L. Cabanillas ${ }^{1}$ \\ ${ }^{I}$ Preventive Medicine and Public Health Department. University of Seville. Seville, Spain. ${ }^{2}$ Preventive Medicine and \\ Public Health Unit. Virgen Macarena Hospital. Seville, Spain
}

\begin{abstract}
Objectives: analysis of the evolution of colorectal cancer in Spain during the period 1951-2007 and its relationship with diet.

Material and methods: calculation of incidence rates, standardized mortality and years of potential life lost (world population) and per capita consumption of different foods.

Results: red and processed meats, poultry, fish and fruits intake has increased and consumption of vegetables, cereals and legumes has decreased.

The incidence of colorectal cancer has steadily increased in both genders, more markedly among men, and across all age groups, in contrast to what has been observed in other countries. Mortality increased during the period 1951-2000, but from that time until 2007 these rates have kept steady in men and fallen in women.

The years of potential life lost (YPLL) shows a similar distribution to mortality.

The correlation coefficients have values close to one for consumption of red meat, poultry, fish, vegetables and fruits and strongly negative values for the consumption of cereals and vegetables with the incidence and mortality in both genders, and the YPLL, but only among men, with weaker correlations for women.

Conclusions: in colorectal cancer, a minimal time span of ten-fifteen years is necessary for changes in exposure to risk factors to be able to modify the incidence of this tumour. Therefore, Spanish State and Regional Governments should implement legislative and educational measures in the field of Health Promotion regarding the diet urgently.
\end{abstract}

Key words: Colorectal cancer. Incidence. Mortality. diet.

Received: 17-07-09.

Accepted: 11-11-09.

Correspondence: Luis María Béjar Prado. Departamento de Medicina Preventiva y Salud Pública. Facultad de Medicina. Universidad de Sevilla. Avda. Sánchez Pizjuán, s/n. 41007 Sevilla.e-mail: 1mbprado@us.es
Béjar L, Gili M, Ramírez G, López J, Cabanillas JL. Dietary changes and colorectal cancer trends in Spain during 19512007. Rev Esp Enferm Dig 2010; 102: 159-168.

\section{INTRODUCTION}

Many epidemiological studies have identified several risk and protection factors for colorectal cancer $(1,2)$, and some have proved that changes in the exposure to these factors may have an influence on incidence and mortality due to this kind of tumor. A remarkable fact is that many of these factors are associated to people's behavior and, therefore, are potentially avoidable or subject to change $(3,4)$.

Among those factors related to people's behavior, the described risk factors include an excessive consumption of red and processed meats (5-10), low consumption of vegetables and folic acid (11-15), smoking (16), excessive alcohol intake (17), a sedentary lifestyle, overweight and obesity (18-21) and diabetes (22). On the other hand, fish consumption (9), hormonal replacement therapy (23), oral contraceptives (24), calcium intake (25) and physical exercise (26-28) have been considered as protective factors against this tumor.

Regarding dietary fiber intake, results obtained from many studies are inconsistent (29-33). In a similar way, a meta-analysis of 13 case-control studies did not prove that the consumption of animal fat increased the risk of colorectal cancer after adjustment of total energy (34) and most cohort studies do not support a causal association between this factor and colorectal cancer (35).

There is a 25 -fold variation for colorectal cancer incidence worldwide. This geographic variability is probably a consequence of the differences in the environmental exposure to the different risk and protective factors related 
to this tumor (36). In Spain, incidence of colorectal cancer is currently the second most frequent in women after breast cancer (excluding skin cancer). In men it ranks second after lung cancer or third after lung and prostate, depending on the consulted Cancer Registries (37).

Colorectal cancer represents the second cause of mortality due to cancer after lung cancer. In $2007,13,516$ Spaniards deceased due to colorectal cancer $(7,870$ men and 5,646 women), representing $13.1 \%$ of total deaths due to cancer during that year (38). That same year, the years of potential life lost (YPLL) due to colorectal cancer in men ranked second in the global tumor count after lung cancer and third in women after breast and lung cancer (38).

In other countries trends of incidence and mortality of colorectal cancer have experienced great variations during the second half of the $20^{\text {th }}$ century. In many developed countries like United Kingdom, USA, Australia, France, Canada and Sweden incidence and mortality rates have decreased during this period in contrast to what has occurred in Spain, where a remarkable increase has been observed (3). Consequently, some of those countries with higher rates than Spain in the past show lower values at present (18).

The aim of this study is to analyze the evolution of incidence, mortality and YPLL due to colorectal cancer in Spain during the period 1951-2007 and the association with changes in the dietary patterns of the population during that period.

\section{MATERIAL AND METHODS}

Incidence rates of colorectal cancer adjusted to worldwide population for both men and women were obtained from the Spanish Cancer Registries supervised by the International Agency for Research on Cancer (IARC). These rates are published for periods of 3-5 years. In order to compare mortality rates with YPLL and correlation with annual per capita consumption of dietary variables, incidence rates published in the intermediate year of each period are assigned and a linear interpolation method was used for the remaining years. The only data included were those from the Registries of Navarra and Zaragoza, contiguous regions in North Spain with a population of 600,646 and 923,911 inhabitants, respectively, due to the availability of data since 1973 in Navarra and 1968 in Zaragoza (37,39-43).

Annual data on the number of deaths due to colorectal cancer in Spain -codes 153 and 154 in the $8^{\text {th }}$ and $9^{\text {th }}$ revisions of the International Classification of Diseases (ICD) and C18-C21 in the $10^{\text {th }}$ revision- were obtained from the mortality statistics published by the National Institute of Statistics (INE) in "Mortality according to the cause of death" for the period 1951-2007, which is the last year with available data at the time of finishing this study (38). Data were classified according to gender and quinquennial age groups starting by "zero to four years", except for the last group, which was an open group from "eighty years and older". Similarly, reference populations were obtained halfway through each official year of the "Population Estimates" published by the INE, according to gender and age groups (44).

Specific annual rates were calculated from data on the number of deaths and the reference population, according to gender and age groups. Annual mortality rates adjusted to worldwide population for men and women were obtained by a direct method, using the standard global population for the period 1951-2007 as a reference (37).

It is considered that each person who deceases between ages one and seventy haven't lived an amount of years, those from the age of death until seventy. The YPLL gathers together all those years for global population. The middle point of the age interval was selected in each age group except for " 1 to 4 " in which the middle point was considered age 3 . For the remaining groups ages 7,12 and so on until 77 years old were selected. Once specific YPLL according to gender and age groups were obtained, and using the aforementioned data, annual YPLL rates were calculated. Afterwards, and using the same methodology than for mortality, these results were used to obtain annual YPLL rates for colorectal cancer adjusted to worldwide population in men and women (45). Annual per capita consumption of different food during the period 1961-2003 was calculated using data published by the Food and Agriculture Organization of United Nations (FAO) (46).

Incidence, mortality and annual YPLL rates for colorectal cancer adjusted to worldwide population for men and women and annual per capita consumption of red and processed meats, poultry, fish, fruits, vegetables, cereals and legumes were graphically represented for each available year of the studied variables.

Pearson correlation coefficients were calculated for the variables of food consumption and adjusted rates with a 10-year interval delay, this is, the calculated rates were correlated to consumption data from ten years before. Statistic analysis was performed using STATA 10.0 (StataCorp LP, Texas, USA).

\section{RESULTS}

Annual incidence, mortality and YPLL rates for colorectal cancer adjusted to worldwide population for men and women are shown in figure 1.

Incidence rates increase in Navarra and Zaragoza with a marked slope and in a constant way since 1980 in both genders. This important increase is evident in the remaining Spanish Cancer Registries (37,39-43).

Mortality rate and YPLL are graphically shown as nearly parallel lines with an important increase from 1951 to the beginnings of the $21^{\text {st }}$ century, but with a less marked slope when compared to incidence rates. This in- 


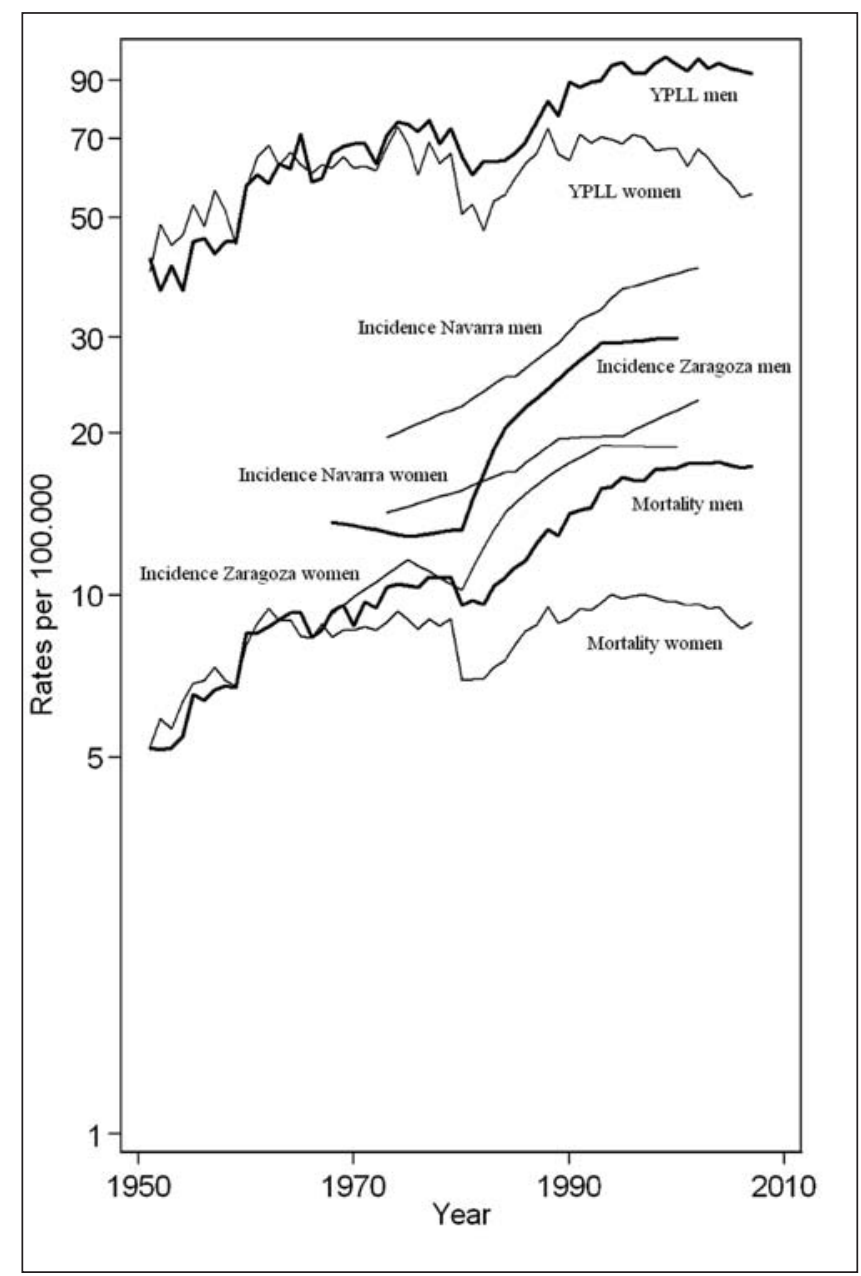

Fig. 1. Annual rates adjusted to worldwide population per 100.000 for incidence, mortality and YPLL in men and women for colorectal cancer. Mortality and YPLL, Spain 1951-2007. Incidence, Navarra, 1973-2002, Zaragoza, 1968-2000.

Tasas anuales ajustadas a la población mundial por 100.000 de incidencia, mortalidad y APVP, en varones y mujeres, por cáncer colorrectal. Mortalidad y APVP, España, 1951-2007. Incidencia, Navarra, 19732002, Zaragoza, 1968-2000.

creasing trend is only interrupted in 1980 when there is a clear fall in both rates and genders. In Spain, the average annual increase during the period 1951-2000 for mortality rate was $4.70 \%$ in men and $1.75 \%$ in women, and for YPLL rate it was $2.63 \%$ in men and $1.4 \%$ in women. However, from that year until 2007, those rates kept steady in men, with an average annual variation of $0.12 \%$ for mortality and $-0.50 \%$ for YPLL In women these values decrease, with an average annual decrease of $1.22 \%$ for mortality and $2.5 \%$ for YPLL. Changes in the consumption of different food during the period 1961-2003 is clearly represented in figures 2 and 3 . In figure 2, a remarkable increase in red and processed meat consumption is observed, especially swine, poultry and fish. In figure 3 , an increase in fruit consumption and a decrease in cereals and legumes, especially beans, consumption is

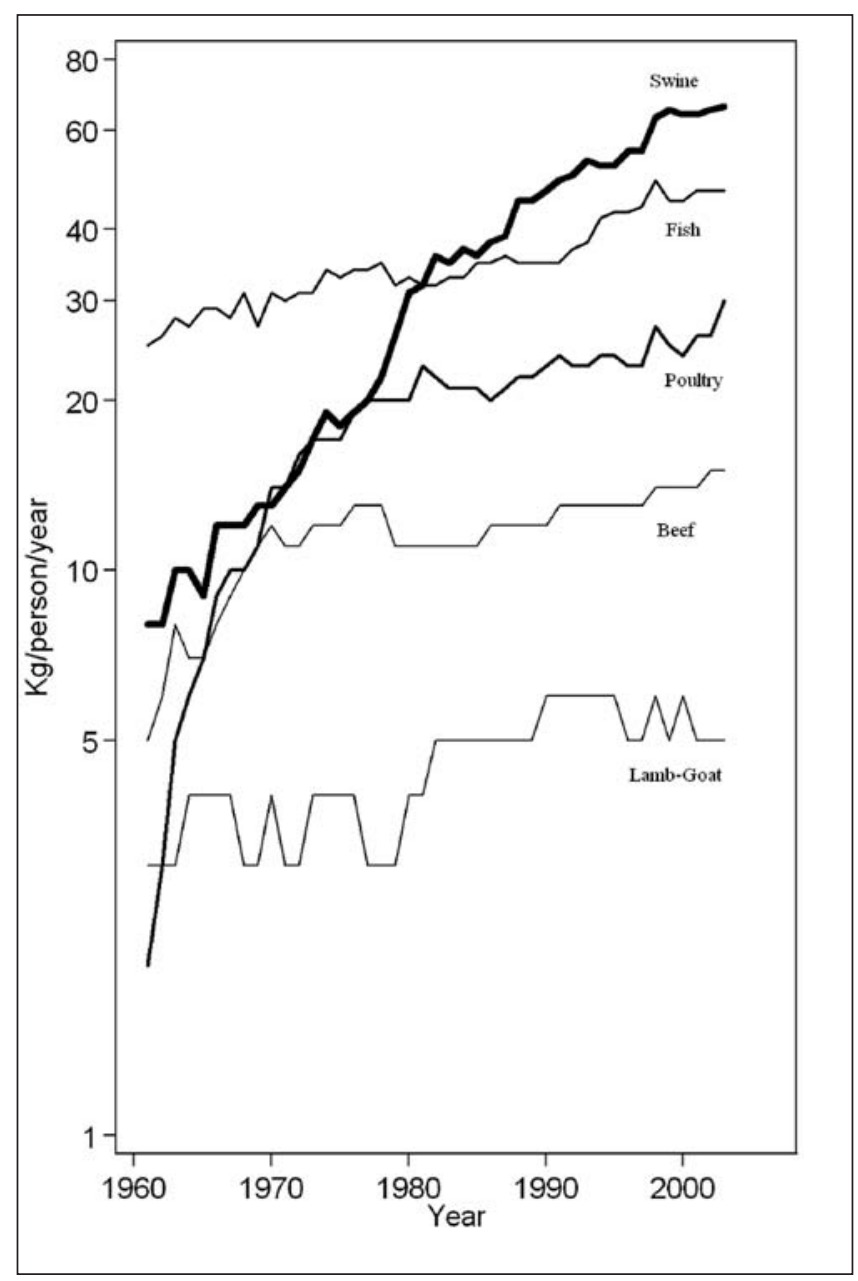

Fig. 2. Annual red meat (swine, beef, lamb/goat), poultry and fish consumption per capita in kilograms. Spain, 1961-2003.

Consumo anual per capita en kilogramos de carnes rojas (cerdo, vacuno, oveja/cabra), pollo y pescado. España, 1961-2003.

observed. Regarding vegetable consumption, an increasing period during the seventies and eighties is followed by a decreasing period from the nineties until 2003.

Table I shows Pearson's correlation coefficients between the studied variables. These are positive and close to one for consumption of red and processed meats, poultry, fish, vegetables and fruit. On the other hand, these values are strongly negative for consumption of cereals and legumes and incidence and mortality in both genders and for YPLL in men, showing weak correlation in women.

\section{DISCUSSION}

Increases in incidence rates indicate that the number of people diagnosed each year of colorectal cancer in Spain is larger in both genders. In a similar way, higher mortality rates and YPLL entail a higher number of deaths and 


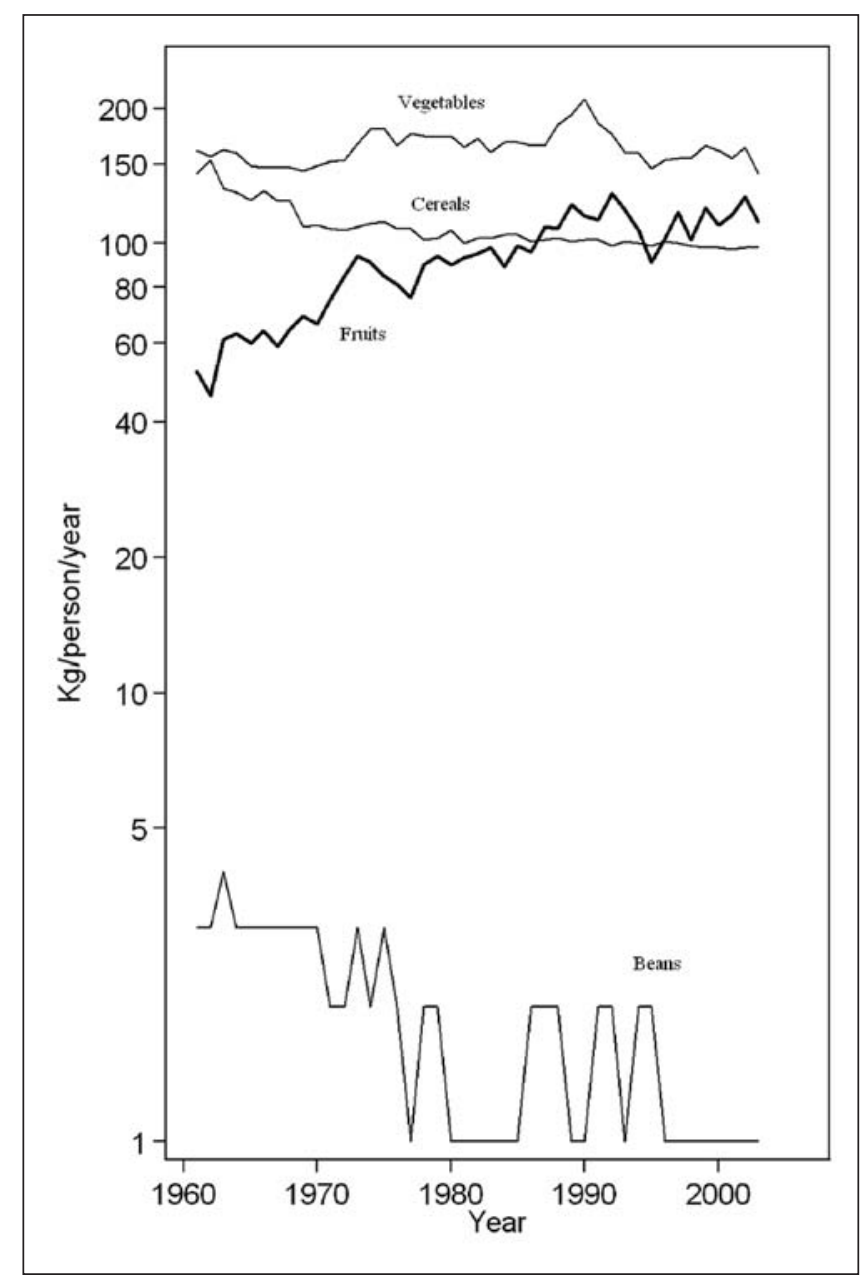

Fig. 3. Annual fruit, vegetables, cereal and bean consumption per capita in kilograms. Spain, 1961-2003.

Consumo anual per capita en kilogramos de frutas, hortalizas, cereales y judías. España, 1961-2003.

premature mortality, respectively. Hence, parallelism between both rates is coherent.

Marked decreases in mortality rate and YPLL in 1980 coincide with the year of implementation of the $8^{\text {th }}$ Review of the ICD. Coding changes may substantially modify mortality trends due to specific causes the year of their implementation (47). During the period 1980-2000, mortality rate and YPLL have decelerated their growth in men even stabilizing or decreasing in women. On the other hand, incidence rates have kept constantly increasing in both genders.

The remarkable increase in red and processed meats consumption as the source of proteins instead of legumes during the last years helps explaining increases in incidence, mortality and YPLL in both genders due to colorectal cancer in Spain during the second half of the $20^{\text {th }}$ century. This increase is parallel to a greater income in Spain. On the other hand, fish consumption increased in a moderate way probably due to higher prices compared to read and processed meats and poultry.
Differences between incidence and mortality rates may be explained by higher survival rates for colorectal cancer as observed in Cancer Registries during the period 1985-1999 (48-50). This increase has been observed in many European countries, in part due to a better diffusion of specific cancer protocols in situ, of adjuvant chemotherapy, pre-surgical radiotherapy and extended use of mesorectal excision to reduce local recurrence in rectal cancer (51-54). Screening programs in colorectal cancer have been infrequent in Spain during that period. Although excellent local studies have been carried out analyzing the efficacy and feasibility of the implementation of early detection programs of colorectal cancer in our environment $(55,56)$, national programs haven't been implemented (as in the case of cervix and breast cancer), therefore it is likely improbable that they exert important effects among survival.

An important difference according to gender is observed in the calculated rates, with higher values in men. Considering incidence, it can be explained by a higher exposure of men to risk factors relates to lifestyle like diet, smoking, excessive alcohol consumption, sedentary lifestyle, overweight, obesity and diabetes. As for mortality and YPLL differences are probably due to an increase in survival for women, which also explains the decreasing trend of these factors in the last years in this group. Higher survival rates in women, not only for colorectal cancer but for other kinds of cancer, has been associated to several factors like a younger age at the time of diagnosis, a better control of their health state and hormonal factors. Likewise, it has also been related to the prevalence of certain comorbidities, especially in those cases in which a particular factor like smoking or excessive alcohol consumption are associated to a higher risk of incidence or mortality due to cancer or other pathologies as cardiovascular, respiratory or hepatic diseases (54).

It is estimated that in middle-aged men the attributable risk percent of colon cancer to 6 risk factors, including red meat and folic acid consumption, is $71 \%$ (57). In a recent study carried out in the United Kingdom about the effects of modifying five behavioral risk factors, including the decrease of red meat consumption and an increase in fruit and vegetable intake, researchers concluded that these measures explained the fall of colorectal cancer rates at present and for future studies in the country (3).

For colorectal cancer, at least 10-15 years are necessary to report visible effects in the tumor incidence after changes in the exposure to risk factors. Therefore, applying effective legislative and educational measures in Spain in terms of Health Promotion to encourage a healthy lifestyle is an urgent matter. These primary prevention measures for colorectal cancer may yield greater benefits in terms of avoidable deaths than national screening programs and treatment improvements in both genders and in every age-group $(3,57)$. However, these measures aren't excluding but complementary to those aforementioned. On the other hand, these legislative and 
Table I. Pearson correlation coefficients for diet variables with annual rates adjusted to worldwide population per 100,000 for incidence (Navarra and Zaragoza), mortality and YPLL (Spain) in men and women, for colorectal cancer with a 10-year delay

\begin{tabular}{|c|c|c|c|c|c|c|c|c|}
\hline \multirow[t]{2}{*}{ Variable } & \multicolumn{2}{|c|}{ Incidence Navarra } & \multicolumn{2}{|c|}{ Incidence Zaragoza } & \multicolumn{2}{|c|}{ Mortality } & \multicolumn{2}{|c|}{ YPLL } \\
\hline & Men & Women & Men & Women & Men & Women & Men & Women \\
\hline Cereals & -0.79 & -0.83 & -0.76 & -0.74 & -0.71 & -0.23 & -0.62 & -0.01 \\
\hline Fruits & 0.92 & 0.94 & 0.90 & 0.88 & 0.86 & 0.42 & 0.77 & 0.07 \\
\hline Vegetables & 0.69 & 0.74 & 0.71 & 0.69 & 0.41 & 0.34 & 0.37 & 0.27 \\
\hline Beans & -0.71 & -0.73 & -0.84 & -0.83 & -0.71 & -0.38 & -0.67 & -0.14 \\
\hline Poultry & 0.88 & 0.92 & 0.90 & 0.89 & 0.83 & 0.35 & 0.72 & 0.04 \\
\hline Swine & 0.99 & 0.98 & 0.95 & 0.94 & 0.97 & 0.54 & 0.90 & 0.09 \\
\hline Beef & 0.60 & 0.67 & 0.63 & 0.60 & 0.61 & 0.08 & 0.46 & -0.17 \\
\hline Lamb / goat & 0.80 & 0.73 & 0.70 & 0.70 & 0.86 & 0.53 & 0.81 & 0.14 \\
\hline Fish & 0.85 & 0.87 & 0.85 & 0.84 & 0.80 & 0.27 & 0.67 & -0.15 \\
\hline
\end{tabular}

Incidence in Navarra: food consumption during the period 1963-1992 was correlated to incidence from 1973 to 2002 . Observations $=29$. Incidence Zaragoza: food consumption during the period 1961-1990 was correlated to incidence from 1971 to 2000 . Observations $=30$. Mortality: food consumption during the period 1961-1997 was correlated to mortality from 1971 to 2007 . Observations = 37 .

YPLL: food consumption during the period 1961-1997 was correlated to YPLL from 1971 to 2007. Observations = 37.

educational measures concerning diet and other behavioral risk factors for colorectal cancer like smoking, excessive alcohol intake and physical exercise have an added value as they are excellent primary prevention measures among other chronic diseases with a greater impact on morbimortality in Spain.

\section{ACKNOWLEDGMENTS}

This study has been partially funded by Instituto de Salud Carlos III (Grant ENTS Nº1/1033).

\section{REFERENCES}

1. Rodrigo L, Riestra S. Diet and colon cancer. Rev Esp Enferm Dig 2007; 99: 183-9.

2. Solera J, Tarraga PJ, Carbayo JA, Lopez MA, Celada A, Cerdan M, et al. Influence of diet and lifestyle in colorectal cancer. Rev Esp Enferm Dig 2007; 99: 190-200.

3. Parkin DM, Olsen AH, Sasieni P. The potential for prevention of colorectal cancer in the UK. Eur J Cancer Prev 2009; 18: 179-90.

4. Platz EA, Willett WC, Colditz GA, Rimm EB, Spiegelman DL, Giovannucci EL. Proportion of colon cancer risk that might be preventable in a cohort of middle-aged US men. Cancer Causes Control 2000; 11: $579-88$

5. Sandhu MS, White IR, McPherson K. Systematic review of the prospective cohort studies on meat consumption and colorectal cancer risk: a meta-analytical approach. Cancer Epidemiol Biomarkers Prev 2001; 10: 439-46.

6. Norat T, Lukanova A, Ferrari P, Riboli E. Meat consumption and colorectal cancer risk: dose-response meta-analysis of epidemiological studies. Int J Cancer 2002; 98: 241-56.

7. Kono S. Secular trend of colon cancer incidence and mortality in relation to fat and meat intake in Japan. Eur J Cancer Prev 2004; 13: 127-32.

8. English DR, MacInnis RJ, Hodge AM, Hopper JL, Haydon AM, Giles GG. Red meat, chicken, and fish consumption and risk of colorectal cancer. Cancer Epidemiol Biomarkers Prev 2004; 13: 1509-14.

9. Norat T, Bingham S, Ferrari P, Slimani N, Jenab M, Mazuir M, et al Meat, fish, and colorectal cancer risk: the European Prospective Investigation into Cancer and Nutrition. J Natl Cancer Inst 2005; 97 : 906-16.
10. Chao A, Thun MJ, Connell CJ. Meat consumption and risk of colorectal cancer. JAMA 2005; 293: 172-82.

11. Steinmetz KA, Potter JD. Vegetables, fruit, and cancer prevention: a review. J Am Diet Assoc 1996; 96: 1027-39.

12. Michels KB, Giovannucci E, Joshipura KJ, Rosner BA, Stampfer MJ, Fuchs CS, et al. Prospective study on fruit and vegetable consumption and incidence of colon and rectal cancers. J Natl Cancer Inst 2000; 92: 1740-52.

13. Terry P, Giovannucci E, Michels KB, Bergkvist L, Hansen H, Holmberg L, et al. Fruit, vegetables, dietary fiber, and risk of colorectal cancer. J Natl Cancer Inst 2001; 93: 525-33.

14. Lanza E, Schatzkin A, Daston C, Corle D, Freedman L, Ballard-Barbash R, et al. Implementation of a 4-y, highfiber, high-fruit-and-vegetable, low-fat dietary intervention: results of dietary changes in the Polyp Prevention Trial. Am J Clin Nutr 2001; 74: 387-401.

15. Riboli E, Norat T. Epidemiologic evidence of the protective effect of fruit and vegetables on cancer risk. Am J Clin Nutr 2003; 78 (Supl.): 559-69.

16. Botteri E, Iodice S, Bagnardi V, Raimondi S, Lowenfels AB, Maisonneuve P. Smoking and colorectal cancer: a meta-analysis. JAMA 2008; 300: 2765-78

17. Cho E, Smith-Warner SA, Ritz J, van den Brandt PA, Colditz GA, Folsom AR, et al. Alcohol intake and colorectal cancer: a pooled analysis of 8 cohort studies. Ann Intern Med 2004; 140: 603-13.

18. World Cancer Research Fund / American Institute for Cancer Research. Policy and action for cancer prevention. Food, nutrition, and physical activity: a global perspective. Washington DC: 2009.

19. Calle EE, Thun MJ. Obesity and cancer. Oncogene 2004; 23: 636578

20. Pischon T, Lahmann PH, Boeing H, Friedenreich C, Norat T, Tjønneland A, et al. Body Size and risk of colon and rectal cancer in the European Prospective Investigation into Cancer and Nutrition (EPIC). J Natl Cancer Inst 2006; 98: 920-31.

21. Larsson SC, Wolk A. Obesity and colon and rectal cancer risk: a meta-analysis of prospective studies. Am J Clin Nutr 2007; 86: 55665

22. Larsson SC, Orsini N, Wolf A. Diabetes mellitus and risk of colorectal cancer: a meta-analysis. J Natl Cancer Inst 2005; 97: 1679-87.

23. Grodstein F, Newcomb PA, Stampfer MJ. Postmenopausal hormone therapy and the risk of colorrectal cancer: a review and meta-analysis. Am J Med 1999; 106: 574-82.

24. Fernandez E, La Vecchia C, Balducci A, Chatenoud L, Franceschi S, Negri E. Oral contraceptives and colorrectal cancer risk: a metaanalysis. Br J Cancer 2001; 84: 722-27.

25. Cho E, Smith-Warner SA, Spiegelman D, Beeson WL, Van den Brandt PA, Colditz GA, et al. Dairy foods, calcium, and colorectal cancer: a pooled analysis of 10 cohort studies (erratum published in $\mathbf{J}$ Natl Cancer Inst 2004; 96: 1724). J Natl Cancer Inst 2004; 96: 101522. 
26. Paffenbarger R, Hyde R, Wing A, Lee IM, Jung D, Kampert J. The association of changes in physical activity level and other lifestyle characteristics with mortality among men. N Engl J Med 1993; 328: 538-45.

27. Colditz GA, Samplin-Salgado M, Ryan CT, Dart H, Fisher L, Tokuda A, et al. Harvard Report on Cancer Prevention, Volume 5. Fulfilling the potential for cancer prevention: policy approaches. Cancer Causes Control 2002; 13: 199-212.

28. Wolin KY, Yan Y, Colditz GA, Lee IM. Physical activity and colon cancer prevention: a meta-analysis. Br J Cancer 2009; 100: 611-6.

29. Bingham SA, Day NE, Luben R, Ferrari P, Slimani N, Norat T, et al. Dietary fibre in food and protection against colorectal cancer in the European Prospective Investigation into Cancer and Nutrition (EPIC): an observational study. Lancet 2003; 361: 1496-501.

30. Park Y, Hunter DJ, Spiegelman D, Bergkvist L, Berrino F, van den Brandt PA, et al. Dietary fiber intake and risk of colorectal cancer: a pooled analysis of prospective cohort studies. JAMA 2005; 294 : 2849-57.

31. Alberts DS, Martinez ME, Roe DJ, Guillen-Rodriguez JM, Marshall JR, van Leeuwen JB, et al. Lack of effect of a high-fiber cereal supplement on the recurrence of colorectal adenomas. Phoenix Colon Cancer Prevention Physicians' Network. N Engl J Med 2000; 342: 1156-62.

32. Schatzkin A, Lanza E, Corle D, Lance P, Iber F, Caan B, et al. Lack of effect of a low-fat, highfiber diet on the recurrence of colorectal adenomas. Polyp Prevention Trial Study Group. N Eng1 J Med 2000; 342: 1149-55.

33. Baron JA. Dietary fiber and colorectal cancer: an ongoing saga. JAMA 2005; 294: 2904-6.

34. Howe GR, Aronson KJ, Benito E, Castelleto R, Cornee J, Duffy S, et al. The relationship between dietary fat intake and risk of colorectal cancer - evidence from the combined analysis of 13 case-control studies. Cancer Causes Control 1997; 8: 215-28.

35. Willett WC. Goals for nutrition in the year 2000. CA Cancer J Clin 1999; 49: 331-52.

36. Parkin DM. International variation. Oncogene 2004; 23: 6329-40.

37. Curado MP, Edwards B, Shin HR, Storm H, Ferlay J, Heanue M, et al., editores. Cancer incidence in five continents. Vol. IX. Lyon: IARC Press; 2007.

38. Instituto Nacional de Estadística. Defunciones según la Causa de Muerte: 2009. Disponible en: http://www.ine.es/

39. Cancer incidence in five continents. Vol I-IV. Available at: http://www-dep.iarc.fr

40. Muir CS, Waterhouse J, Mack T, Powell J, Whelan SL, editores Cancer incidence in five continents. Vol. V. Lyon: IARC Press; 1987.

41. Parkin DM, Muir CS, Whelan SL, Gao Y-T, Ferlay J, Powell J, editors. Cancer incidence in five continents. Vol. VI. Lyon: IARC Press; 1992.

42. Parkin DM, Whelan SL, Ferlay J, Raymond L, Young J, editores.
Cancer incidence in five continents. Vol. VII. Lyon: IARC Press; 1997.

43. Parkin DM, Whelan SL, Ferlay J, Teppo L, Thomas DB, editores. Cancer incidence in five continents. Vol. VIII. Lyon: IARC Press; 2002.

44. Instituto Nacional de Estadística. Estimaciones de Población: 2009 Disponible en: http://www.ine.es/

45. Romeder JM, McWhinnie JR. Potential years of life lost between ages 1 and 70: an indicator of premature mortality for health planning. Int J Epidemiol 1977; 6: 143-51.

46. Food and Agriculture Organization of United Nations. FAOSTAT Crops primary equivalent and livestock and fish primary equivalent consumption statistics, 1961-2003. Available at: http://faostat.fao.org/

47. Janssen F, Kunst AE. ICD coding changes and discontinuities in trends in cause-specific mortality in six European countries, 1950-99. Bull World Health Organ 2004; 82: 904-13.

48. Berrino F, Capocaccia R, Esteve J, Gatta G, Hakulinen T, Micheli A, et al., editores. Survival of cancer patients in Europe: the EUROCARE-2 study. Lyon: IARC Press; 1999.

49. Berrino F, De Angelis R, Sant M, Rosso S, Bielska-Lasota M, Coebergh JW, et al. Survival for eight major cancers and all cancers combined for European adults diagnosed in 1995-99: results of the EUROCARE-4 study. Lancet Oncol 2007; 8: 773-83.

50. Sant M, Aareleid T, Berrino F, Bielska Lasota M, Carli PM, Faivre J et al. EUROCARE-3: survival of cancer patients diagnosed 1990-94-results and commentary. Annal Oncol 2003; 14 (Supl. 5): 61-118.

51. Sauer R, Becker H, Hohenberger W, Rodel C, Wittekind C, Fietkau $\mathrm{R}$, et al. Preoperative versus postoperative chemoradiotherapy for rectal cancer. N Engl J Med 2004; 351: 1731-40.

52. Verdecchia A, Francisci S, Brenner H, Gatta G, Micheli A, Mangone L, et al. Recent cancer survival in Europe: a 2000-02 period analysis of EUROCARE-4 data. Lancet Oncol 2007; 8: 784-96.

53. Jessup JM, Stewart A, Greene FL, Minsky BD. Adjuvant chemotherapy for stage III colon cancer: implications of race/ethnicity, age, and differentiation. JAMA 2005; 294: 2703-11.

54. Micheli A, Ciampichini R, Oberaigner W, Ciccolallo L, de Vries E, Izarzugaza I, et al. The advantage of women in cancer survival: an análisis of EUROCARE-4 data. Eur J Cancer 2009; 45: 1017-27.

55. Diaz J, Marin JC. Colorectal cancer screening with fecal occult blood testing. Rev Esp Enferm Dig 2008; 100: 315-9.

56. Navarro M, Peris M, Binefa G, Nogueira JM, Miquel JM, Espinas JA, et al. Colonoscopic findings from a pilot screening study for colorectal cancer in Catalonia. Rev Esp Enferm Dig 2008; 100: 343-8.

57. Platz EA, Willett WC, Colditz GA, Rimm EB, Spiegelman DL, Giovannucci EL. Proportion of colon cancer risk that might be preventable in a cohort of middle-aged US men. Cancer Causes Control 2000; 11: $579-88$. 